\title{
UTILIZATION OF ORGANIC LIQUID WAS TEAS FERTILIZER WITH DIFFERENT CONCENTRATION ON THE GROWTH AND YIELD OF BOK CHOY (BRASSICA RAPA VAR. CHINENSIS)
}

\author{
Restu Dwi Nugroho ${ }^{1)}$, Muhammad Anshar Pasigai ${ }^{2)}$, Bahrudin $^{2)}$ \\ Agrotechnology Program, Faculty of Agriculter, University of Tadulako, Palu, Email: restudwinugroho55@gmail.com \\ Faculty of Agriculture, University of Tadulako, Palu, ansharpasigai@gmail.com
}

\begin{abstract}
This research aimedto study the influence ofthe right type and concentration organic waste on the growth and yield of bok choy. This research was compiled using a randomized block design factorial with two treatment factors, The first factor type of waste, second factor of concentration spraying. Thus obtained 8 experimental unitsconsists oforganic liquid waste cow urine (concentration of $20 \%, 40 \%, 60 \%$ and $80 \%$ ), organic liquid waste water catfish pond (concentration of $20 \%, 40 \%, 60 \%$ and $80 \%$ ). Each unit treatment was repeated three times so that there were 24 experimental units. The observed variables includeplant height $(\mathrm{cm})$, leaves number, fresh weight of roots stems and leaves (g), dry weight of roots, stems and leaves (g), the amount of leaf $\left(\mathrm{cm}^{2}\right)$, and the fresh weight of the plants $\left(\right.$ ton $\left.\mathrm{ha}^{-1}\right)$. The results showed that interaction between the type of organic liquid waste concentration of $40 \%$ (equivalent to $40 \mathrm{~mL} \mathrm{~L}^{-1}$ ) gives better results than other concertation, Types of organic waste liquid cow urinegave better resultsthanorganic liquid waste water catfish pond, and the concentration better of organic liquid waste in a concentration of $40 \%$ (equivalent to $40 \mathrm{~mL} \mathrm{~L}^{-1}$ ).
\end{abstract}

Key Words : Cow Urine, Bok Choy, Manure, Organic Liquid Waste, Water Catfish Pond.

\section{INTRODUCTION}

In modern farming systems, the use of inorganic fertilizers has been proven to increase yields. This condition makes farmers heavily dependent on inorganic fertilizers and tends to deliver them in high doses. Continuous and long-term use can have negative impacts on the environment and decrease the quality of some vegetable commodities. To reduce the negative impact, one way that can be done by developing more environmentally friendly organic farming by using organic fertilizers such as cow urine liquid fertilizer (Devani, 2012).

In addition to cow urine, catfish pond water can also be used as an alternative to inorganic liquid fertilizer, catfish pond water can increase the production of mustard and lettuce plants as much as $25 \%$ compared to without fertilizer (Deptan, 1999).
Based on the description of the above problems, it is necessary to do research about "Utilization of Organic Liquid Wasteas Fertilizer with Different Concentration on the Growth and Yield of Bok Choy".

\section{RESEARCH METHODS}

Location and Time of Research. This research was conducted in Dusun Bolupontu Jaya, SigiBiromaru Sub-district, Sigi Regency. Soil and plant analysis was conducted at Soil Science Laboratory, Faculty of Agriculture, Tadulako University of Palu. The study took place from May 2016 to 2016.

Tools and Materials.ring samples, sacks, machetes, shovels, hoes, sample envelopes, paper labels, analytical scales, plastic bags, 7 and 25 liters jerry cans, water can, 
sprinkler, plastic sample, oven, paranet, 100 $\mathrm{ml}$ measuring cup, hand spray, leave area meters, buckets, and stationery.

The materials used were seed of Chinese cabbage (bok choy), cow manure, organic liquid waste of catfish pond and cow urine, as well as laboratory chemicals.

Research Method. This research was arranged using Randomized Block Design (RBD) factorial pattern with two treatment factors. The first factor was the type of waste while the second factor was the concentration of spraying. So there were 8 treatment combinations of organic cow urine liquid waste (concentration of $20 \%$ (P1K1), 40\% (P1K2), 60\% (P1K3) and concentration of $80 \%$ (P1K4)). Liquid waste of catfish pond (concentration of $20 \%$ (P2K1), 40\% (P2K2), 60\% (P2K3) and concentration of $80 \%$ (P2K4)). Observation variables in this study were plant height (cm), number of leaves, fresh weight of root, stem, and leaf (g), dry weight of root, stem, and leaf $(\mathrm{g})$, total leaf area per plant (cm2), and fresh weight of plant (ton ha-1). Data obtained from this research were analyzed by using analysis of Variance. Analysis of variance which showed significant or very real effect followed by honestly significant different test (HSD) to know the difference of average value between treatments tested.

The implementation of this research included initial soil analysis, organic waste water manure analysis, land preparation, seeding, planting, treatment, maintenance consisting of watering and weeding, and harvesting.

\section{RESULTS AND DISCUSSIONS}

\section{Results}

Plant height (cm).The analysis of variance showed that organic wastewater type, spraying concentration, and interaction between treatments did not affect plant height $(\mathrm{cm})$ at plant age of 15 DAP and 30 DAP.

Number of leaves. The analysis of variance showed that organic wastewater type, concentration of spraying, and interaction between treatments did not affect the number of leaves at plant age of 15 DAP and 30 DAP.

Leaf area $\left(\mathrm{cm}^{2}\right)$. The analysis of variance showed that organic wastewater type, spray concentration, and treatment interaction had a significant effect on the observation of plant on 15 DAP and 30 DAP. The average leaf area is presented in Table 1.

Table 1.The average leaf area $\left(\mathrm{cm}^{2}\right)$ of bok choy plant on 15 DAP and 30 DA Pagainst application of various concentrations of organic wastewater spraying.

\begin{tabular}{|c|c|c|c|c|c|c|}
\hline \multirow{2}{*}{ Plant Age } & \multirow{2}{*}{ Type of Waste } & \multicolumn{4}{|c|}{ Spraying Concentration } & \multirow{2}{*}{ HSD $5 \%$} \\
\hline & & 20 & 40 & 60 & 80 & \\
\hline \multirow{3}{*}{15 DAP } & Cow urine & $22.49_{y}^{c}$ & $34.65^{b}$ & $22.96_{y}^{c}$ & $58.59_{x}^{a}$ & \multirow[b]{2}{*}{2.77} \\
\hline & $\begin{array}{l}\text { Catfish pond } \\
\text { water }\end{array}$ & $34.79^{a}{ }_{x}$ & $26.90^{\mathrm{b}}$ & $34.98_{\mathrm{x}}^{\mathrm{a}}$ & $29.15_{\mathrm{y}}^{\mathrm{b}}$ & \\
\hline & HSD 5\% & & & 3.75 & & \\
\hline \multirow{3}{*}{30 DAP } & Cow urine & $37.25^{\mathrm{c}} \mathrm{x}$ & $51.18^{\mathrm{a}}$ & $40.95^{\mathrm{bc}}$ & $44.76_{x}^{b}$ & \multirow[b]{2}{*}{5.24} \\
\hline & $\begin{array}{l}\text { Catfish pond } \\
\text { water }\end{array}$ & $33.43^{b}$ & $38.04_{\mathrm{y}}^{\mathrm{b}}$ & $45.95^{\mathrm{a}} \mathrm{x}$ & $37.66^{b}{ }_{x}$ & \\
\hline & HSD 5\% & & & 7,11 & & \\
\hline
\end{tabular}

Information:The numbers followed by the letters in rows (a, b) and columns ( $x, y)$ of each plant age did not have differences from the 5\% HSD test. 
Table 2. The average dry weight of (g) bok choy leafon 15 DAPagainst application of various concentrations of organic wastewater spraying.

\begin{tabular}{ccc}
\hline Concentration $(\%)$ & Average dry weight of leaf(g) 15 DAP & HSD 5\% \\
\hline 20 & $2.97^{\mathrm{ab}}$ & \\
40 & $3.61^{\mathrm{a}}$ & 0.62 \\
60 & $2.68^{\mathrm{b}}$ & \\
80 & $3.00^{\mathrm{ab}}$ & \\
\hline
\end{tabular}

Information : The numbers followed by the letters in rows $(a, b)$, did not have differences from the 5\% HSD $\ldots$

Table 3.The average dry weight of $(\mathrm{g})$ bok choy leaf on 30 DAP against application of various concentrations of organic wastewater spraying.

\begin{tabular}{|c|c|c|c|c|c|c|}
\hline \multirow{2}{*}{ Type of waste } & \multicolumn{4}{|c|}{ Spraying Concentration } & \multirow[t]{2}{*}{ Average } & \multirow[t]{2}{*}{ HSD 5\% } \\
\hline & 20 & 40 & 60 & 80 & & \\
\hline Cow urine & 5.78 & 6.78 & 6.10 & 5.65 & $6.33^{\mathrm{b}}$ & \multirow{2}{*}{1.01} \\
\hline Catfish pond water & 6.29 & 8.21 & 6.73 & 7.86 & $7.27^{\mathrm{a}}$ & \\
\hline Average & $6.03^{b}$ & $7.50^{\mathrm{a}}$ & $6.42^{\mathrm{b}}$ & $.25^{\mathrm{a}}$ & & \\
\hline HSD 5\% & & & 0.75 & & & \\
\hline
\end{tabular}

Information : The numbers followed by the letters in rows (a, b), did not have differences from the 5\% HSD test.

The 5\% HSD test results (Table 2) showed that at the age of 15 days after planting (DAP), the combination of organic cow urine organic waste treatment with $80 \%$ concentration (equivalent to $80 \mathrm{~mL} \mathrm{~L}^{-}$ $\left.{ }^{1}\right)$ gave the highest average leaf area of $58,59 \mathrm{~cm}^{2}$ which was different from other concentration, while the combination of cow urine treatment of $20 \%$ concentration (equivalent to $20 \mathrm{~mL} \mathrm{~L}^{-1}$ ) had the lowest average leaf area of $22.49 \mathrm{~cm}^{2}$ but there was no difference at $60 \%$ concentration (equivalent to $60 \mathrm{~mL} \mathrm{~L}^{-1}$ ). At the age of 30 DAP, the combination of organic cow urine liquid waste treatment with a concentration of $40 \%$ (equivalent to $40 \mathrm{~mL} \mathrm{~L}^{-1}$ ) had the highest average leaf area of $51.18 \mathrm{~cm}^{2}$ which contrasted with other concentrations. While the combination of organic liquid water treatment of catfish pond concentration of $20 \%$ (equivalent to $80 \mathrm{~mL} \mathrm{~L}^{-1}$ ) resulted in the lowest average leaf area of $37.25 \mathrm{~cm}^{2}$.

Dry weight of leaf (g). The analysis of variance showed that organic wastewater type had significant effect on plant age of 30 DAP but did not affect the plant on
15 DAP, spraying concentration had significant effect on plant age of 15 DAP and 30 DAP, while interaction between treatments had no effect on observation of dry weight leaf on 15 DAP and 30 DAP. Table of average dry weight of leaf is presented in Table 2 and 3.

The 5\% HSD test results (Table 3) showed that at plant age of 15 days after planting (DAP) the highest dry leaf weight was found at concentration of $40 \%$ (equivalent to $40 \mathrm{~mL} \mathrm{~L}^{-1}$ ) that was $3.61 \mathrm{~g}$, while the lowest dry leaf weight was found at $60 \%$ concentration (equivalent to $60 \mathrm{~mL}$ $\mathrm{L}^{-1}$ ) that was $2.68 \mathrm{~g}$.

The 5\% HSD test results (Table 4) showed that at plant age of 30 days after planting (DAP) organic liquid waste water of catfish pond gave the higher result of dry weight of leaf that was $7.27 \mathrm{~g}$, compared with cow urine organic liquid waste that was $6,33 \mathrm{~g}$. While the highest dry leaf weight was found at concentration of $40 \%$ (equivalent to $40 \mathrm{~mL} \mathrm{L-1)}$ that was $7.50 \mathrm{~g}$ but not different at $80 \%$ concentration (equal to $80 \mathrm{~mL} \mathrm{~L}^{-1}$ ), while the lowest dry 
weight of leaf was found at a concentration of $20 \%$ (equivalent to $20 \mathrm{~mL} \mathrm{~L}^{-1}$ ) that was $6.03 \mathrm{~g}$ but not different at concentrations of $60 \%$.

Dry weight of root (g).The analysis of variance showed that the type of organic waste had a very significant effect on plant age of 15 days after planting (DAP) but did not affect the age of 30 DAP. The concentration of organic wastewater effect was very significant at the age of 15 DAP and 30 DAP, whereas the interaction had significant effect on the age of 15 DAP but did not the effect on the age of 30 DAP. The average dry weight of root is presented in Tables 4 and 5.

The 5\% HSD test results (Table 5) showed that combination of liquid wastewater of catfish pond with concentration of $20 \%$ (equal to $20 \mathrm{~mL} \mathrm{~L}^{-1}$ ) yielded highest average dry weight of root at plant age of 15 days after planting (DAP) with root dry weight was $2.31 \mathrm{~g}$, which was different at other concentrations. While the combination of liquid wastewater of catfish pond with concentration of $60 \%$ (equivalent to $60 \mathrm{~mL}$
$\mathrm{L}^{-1}$ ) resulted in the lowest average dry weight with an average dry weight of roots was $1.47 \mathrm{~g}$ which was different from other concentrations.

Based on the 5\% HSD test results, the highest average dry weight of root was found at $80 \%$ concentration (equivalent to $80 \mathrm{~mL} \mathrm{~L}^{-1}$ ) that was $2.55 \mathrm{~g}$, which was different from other concentrations, while the lowest dry weight of root was at $20 \%$ concentration (equivalent to $20 \mathrm{~mL} \mathrm{~L}^{-1}$ ) with an average dry weight of roots was $1.18 \mathrm{~g}$, unlike the concentration of $80 \%$ (equivalent to $80 \mathrm{~mL} \mathrm{~L}^{-1}$ ) but it was not different with other concentrations.

Dry weight of stem (g). The analysis of variance showed that the type of waste had significant effect on the age of 15 DAP but had no effect on the age of 30 DAP, the concentration of spraying had significant effect on the age of 15 DAP, and the interaction of treatment had a significant effect on the age of 15 DAP and 30 DAP. The average dry weight of the stem is presented in Table 6.

Table 4. The average dry weight of (g) bok choy root on 15 DAP against application of various concentrations of organic wastewater spraying.

\begin{tabular}{|c|c|c|c|c|c|}
\hline \multirow{2}{*}{ Type of Waste } & \multicolumn{4}{|c|}{ Spraying Concentration } & \multirow{2}{*}{ HSD 5\% } \\
\hline & 20 & 40 & 60 & 80 & \\
\hline Cow urine & $1.58^{\mathrm{ab}} \mathrm{y}$ & $1.66^{\mathrm{a}}$ & $1.51^{\mathrm{b}}{ }_{\mathrm{x}}$ & $1.60^{\mathrm{a}}{ }_{\mathrm{x}}$ & \multirow[b]{2}{*}{0.08} \\
\hline Catfish pond water & $2.31_{\mathrm{x}}^{\mathrm{a}}$ & $1.67^{\mathrm{b}}$ & $1.47_{\mathrm{x}}^{\mathrm{d}}$ & $1.56_{\mathrm{x}}^{\mathrm{c}}$ & \\
\hline HSD $5 \%$ & & & 0,11 & & \\
\hline
\end{tabular}

Information: The numbers followed by the letters in rows $(\mathrm{a}, \mathrm{b})$ and columns $(\mathrm{x}, \mathrm{y})$ of each plant age did not have differences from the 5\% HSD test.

Table 5. The average dry weight of (g) bok choy root on 30 DAP against application of various concentrations of organic wastewater spraying

\begin{tabular}{ccc}
\hline Concentration $(\%)$ & Average dry weight of leaf $(\mathrm{g})$ 15 DAP & HSD 5\% \\
\hline 20 & $2.18^{\mathrm{b}}$ & \\
40 & $2.37^{\mathrm{ab}}$ & 0.62 \\
60 & $2.27^{\mathrm{ab}}$ & \\
80 & $2.55^{\mathrm{a}}$ & \\
\hline
\end{tabular}

Information: The numbers followed by the letters in rows did not have differences from the 5\% HSD test. 
Table 6.The average dry weight of (g) bok choy stem on 15 and 30 DAP against application of various concentrations of organic wastewater spraying.

\begin{tabular}{|c|c|c|c|c|c|c|}
\hline \multirow{2}{*}{ Plant age } & \multirow{2}{*}{ Type of waste } & \multicolumn{4}{|c|}{ Spraying Concentration } & \multirow{2}{*}{ HSD 5\% } \\
\hline & & 20 & 40 & 60 & 80 & \\
\hline \multirow{3}{*}{$15 \mathrm{DAP}$} & Cow urine & $1.58_{y}^{\mathrm{c}}$ & $2.01^{a}{ }_{x}^{a}$ & $1.71_{x}^{b}$ & $1.97^{\mathrm{a}}{ }_{\mathrm{x}}$ & \multirow[b]{2}{*}{0.12} \\
\hline & Catfish pond water & $2.04^{\mathrm{a}}{ }_{\mathrm{x}}$ & $1.81_{\mathrm{y}}^{\mathrm{b}}$ & $1.87^{\mathrm{b}}$ & $1.89^{\mathrm{b}} \mathrm{x}$ & \\
\hline & HSD 5\% & & 0. & & & \\
\hline \multirow{3}{*}{$30 \mathrm{DAP}$} & Cow urine & $2.29^{b}{ }_{x}$ & $2.60^{\mathrm{a}}$ & $2.23^{\mathrm{b}}$ & $2.58^{\mathrm{a}}$ & \multirow{2}{*}{0.22} \\
\hline & Catfish pond water & $2.11^{\mathrm{b}} \mathrm{x}$ & $2.52^{\mathrm{a}} \mathrm{x}$ & $2.72^{\mathrm{a}} \mathrm{y}$ & $2.59^{\mathrm{a}}{ }_{\mathrm{x}}$ & \\
\hline & HSD $5 \%$ & & 0.29 & & & \\
\hline
\end{tabular}

Information: The numbers followed by the letters in rows $(\mathrm{a}, \mathrm{b})$ and columns $(\mathrm{x}, \mathrm{y})$ of each plant age did not have differences from the $5 \%$ HSD test.

Table7. The average dry weight of (g) bok choy leaf on 15 and 30 DAP against application of various concentrations of organic wastewater spraying.

\begin{tabular}{|c|c|c|c|c|c|c|}
\hline \multirow{2}{*}{ Plant age } & \multirow{2}{*}{ Type of waste } & \multicolumn{4}{|c|}{ Spraying concentration } & \multirow[t]{2}{*}{ HSD 5\% } \\
\hline & & 20 & 40 & 60 & 80 & \\
\hline \multirow{3}{*}{15 DAP } & Cow urine & $6.94_{x}^{c}$ & $10.88^{\mathrm{a}}{ }_{\mathrm{x}}$ & $6.90_{x}^{c}$ & $8.65^{\mathrm{b}}{ }_{\mathrm{x}}$ & \multirow[b]{2}{*}{0.94} \\
\hline & $\begin{array}{l}\text { Catfish pond } \\
\text { water }\end{array}$ & $8.47_{y}^{\mathrm{a}}$ & $9.26_{\mathrm{y}}^{\mathrm{a}}$ & $6.68_{x}^{b}$ & $7.32_{\mathrm{y}}^{\mathrm{b}}$ & \\
\hline & HSD 5\% & & & & & \\
\hline \multirow{3}{*}{30 DAP } & Cow urine & $15.69^{b}$ & $21.08_{x}^{a}$ & $16.89^{b}$ & $17.62_{x}^{b}$ & \multirow[b]{2}{*}{2.59} \\
\hline & $\begin{array}{l}\text { Catfish pond } \\
\text { water }\end{array}$ & $16.24_{\mathrm{x}}^{\mathrm{b}}$ & $18.05_{\mathrm{x}}^{\mathrm{b}}$ & $21.61_{x}^{a}$ & $18.03^{\mathrm{b}}$ & \\
\hline & HSD $5 \%$ & \multicolumn{4}{|c|}{3,51} & \\
\hline
\end{tabular}

Information: The numbers followed by the letters in rows (a, b) and columns (x, y) of each plant age did not have differences from the $5 \%$ HSD test.

The 5\% HSD test results (Table 7) showed that on observation of plant age 15 days after planting (DAP), liquid wastewater of catfish pond with concentration of $20 \%$ (equal to $20 \mathrm{~mL} \mathrm{~L}^{-1}$ ) gave the best influence to dry weight of stem with a dry weight of stems of $2.04 \mathrm{~g}$ in contrast to other concentrations, whereas in combination of organic cow urine liquid waste with the concentration of $20 \%$ (equivalent to $20 \mathrm{~mL} \mathrm{~L}^{-1}$ ) was obtained the lowest average dry weight of stem was 1.58 g. While on 30 DAP, the combination of liquid wastewater of catfish pond with concentration of $80 \%$ (equivalent to $80 \mathrm{~mL}$ $\mathrm{L}^{-1}$ ) resulted in the highest dry weight of stem that was 2.59 g. While the combination of liquid wastewater of catfish pond with concentration of $20 \%$ (equivalent to $20 \mathrm{~mL} \mathrm{~L}^{-1}$ ) resulted in the lowest dry stem weight of $2.11 \mathrm{~g}$.

Fresh weight of leaf $(\mathrm{g})$. The analysis of variance showed that organic wastewater type had no effect on plant age of 15 DAP and 30 DAP. The concentration of organic wastewater effect was very significant at the age of 15 DAP, and the effect was significant on the age of $30 \mathrm{DAP}$, while the treatment interaction was very significant at the age of 15 DAP and 30 DAP. The average dry weight of the stem is presented in Table 7. 
Table7. The average dry weight of (g) bok choy leaf on 15 and 30 DAP against application of various concentrations of organic wastewater spraying.

\begin{tabular}{|c|c|c|c|c|c|c|}
\hline \multirow{2}{*}{ Plant age } & \multirow{2}{*}{ Type of waste } & \multicolumn{4}{|c|}{ Spraying concentration } & \multirow{4}{*}{$\begin{array}{c}\text { HSD 5\% } \\
0.94\end{array}$} \\
\hline & & 20 & 40 & 60 & 80 & \\
\hline \multirow[b]{2}{*}{15 DAP } & Cow urine & $6.94_{x}^{c}$ & $10.88^{\mathrm{a}}{ }_{\mathrm{x}}$ & $6.90^{c}{ }_{x}$ & $8.65^{b}{ }_{x}$ & \\
\hline & $\begin{array}{l}\text { Catfish pond } \\
\text { water }\end{array}$ & $8.47_{\mathrm{y}}^{\mathrm{a}}$ & $9.26_{\mathrm{y}}^{\mathrm{a}}$ & $6.68^{\mathrm{b}}{ }_{\mathrm{x}}$ & $7.32_{\mathrm{y}}^{\mathrm{b}}$ & \\
\hline \multirow{4}{*}{$30 \mathrm{DAP}$} & HSD 5\% & \multicolumn{4}{|c|}{1.27} & \multirow[b]{3}{*}{2.59} \\
\hline & Cow urine & $15.69^{b}{ }_{x}$ & $21.08_{x}^{\mathrm{a}}$ & $16.89^{\mathrm{b}}$ & $17.62^{b}$ & \\
\hline & $\begin{array}{l}\text { Catfish pond } \\
\text { water }\end{array}$ & $16.24_{\mathrm{x}}^{\mathrm{b}}$ & $18.05^{b}$ & $21.61_{x}^{a}$ & $18.03^{b}$ & \\
\hline & HSD 5\% & \multicolumn{4}{|c|}{3,51} & \\
\hline
\end{tabular}

Information: The numbers followed by the letters in rows (a, b) and columns (x, y) of each plant age did not have differences from the $5 \%$ HSD test.

Table 8 . The average dry weight of ( $\mathrm{g}$ ) bok choy root on 15 DAP against application of various concentrations of organic wastewater spraying.

\begin{tabular}{ccc}
\hline Konsentrasi $(\%)$ & Rata-rata bobotkeringdaun(g) 15 DAP & HSD 5\% \\
\hline 20 & $2,88^{\mathrm{ab}}$ & \\
40 & $3,12^{\mathrm{a}}$ & 0,45 \\
60 & $2,66^{\mathrm{b}}$ & \\
80 & $2,81^{\mathrm{ab}}$ & \\
\hline
\end{tabular}

Information: The numbers followed by the letters in rows did not have differences from the 5\% HSD test.

The 5\% HSD test results (Table 8) showed that on observation of plant age of 15 days after planting (DAP), combination of organic cow urine with $40 \%$ concentration (equivalent to $40 \mathrm{~mL} \mathrm{~L}^{-1}$ ) gave the best influence to fresh weight of leaf with average fresh weight of leaf was $10.88 \mathrm{~g}$, whereas in combination of liquid wastewater of catfish pond with concentration of $60 \%$ (equivalent to $60 \mathrm{~mL} \mathrm{~L}^{-1}$ ) was obtained the lowest average fresh weight of leaf that was $6.68 \mathrm{~g}$. Otherwise, on 30 DAP plant age observation, combination of liquid wastewater of catfish pond with concentration of $60 \%$ (equal to $60 \mathrm{~mL} \mathrm{~L}-1$ ) yielded highest fresh weight of leaf that was $21,61 \mathrm{~g}$, vice versa on combination of organic cow urine with $20 \%$ concentration (equivalent to $20 \mathrm{~mL} \mathrm{~L}^{-}$ $\left.{ }^{1}\right)$ yielded lowest fresh weight of leaf of $15.69 \mathrm{~g}$.

Fresh weight of root $(\mathrm{g})$. The analysis of variance showed that the type of organic wastewater and treatment interaction had no effect on all observations. The concentration of organic wastewater effect was very significant at plant age of 15 DAP. The average fresh root weight is presented in Table 8.

Based on observations on plant age of 15 days after planting (DAP) as shown in table 9 after 5\% HSD test, the highest average leaf number was found at concentration of $40 \%$ (equivalent to $40 \mathrm{~mL}$ $\mathrm{L}^{-1}$ ) while average fresh root weight was $3.12 \mathrm{~g}$. While the lowest fresh root weight was at $60 \%$ concentration of $2.66 \mathrm{~g}$.

Fresh weight of stem (g). The analysis of variance showed that the type of organic waste had a very significant effect on the age of 15 DAP plants and did not affect age of 30 DAP plants. The concentration of organic wastewater and treatment interaction had a significant effect on the age of 15 DAP and 30 DAP plants. The average fresh weight of stem is presented in Table 9. 
Table 9. The average fresh weight of (g) bok choy stem on 15 and 30 DAP against application of various concentrations of organic wastewater spraying.

\begin{tabular}{|c|c|c|c|c|c|c|}
\hline \multirow{2}{*}{ Plant age } & \multirow{2}{*}{ Type of waste - } & \multicolumn{4}{|c|}{ Konsentrasipenyemprotan } & \multirow[t]{2}{*}{ HSD 5\% } \\
\hline & & 20 & 40 & 60 & 80 & \\
\hline \multirow{3}{*}{15 DAP } & Cow urine & $2.07_{x}^{b}$ & $2.72^{\mathrm{a}} \mathrm{x}$ & $2.02^{\mathrm{b}}{ }_{\mathrm{x}}$ & $2.04_{x}^{b}$ & \multirow[b]{2}{*}{0.12} \\
\hline & Catfish pond wats & $2.02^{b}$ & $2.28_{\mathrm{y}}^{\mathrm{a}}$ & $1.97^{\mathrm{b}} \mathrm{x}$ & $1.85_{\mathrm{y}}^{\mathrm{c}}$ & \\
\hline & HSD 5\% & & & & & \\
\hline \multirow[t]{2}{*}{30 DAP } & $\begin{array}{c}\text { Cow urine } \\
\text { Catfish pond wat }\end{array}$ & $\begin{array}{l}6.85^{\mathrm{b}} \\
9.34_{\mathrm{x}}^{\mathrm{b}}\end{array}$ & $\begin{array}{c}13.06^{\mathrm{a}}{ }_{\mathrm{x}} \\
5.83_{\mathrm{y}}^{\mathrm{c}} \\
\end{array}$ & $\begin{array}{l}7.90^{\mathrm{b}}{ }_{\mathrm{x}} \\
8.74^{\mathrm{b}}{ }_{\mathrm{x}}\end{array}$ & $\begin{array}{r}9.00^{\mathrm{b}}{ }_{\mathrm{y}} \\
14.12^{\mathrm{a}}{ }_{\mathrm{x}} \\
\end{array}$ & 2.25 \\
\hline & HSD 5\% & & & & & \\
\hline
\end{tabular}

Information: The numbers followed by the letters in rows $(\mathrm{a}, \mathrm{b})$ and columns $(\mathrm{x}, \mathrm{y})$ of each plant age did not have differences from the $5 \%$ HSD test.

Table 10. Fresh weight of the plant (ton ha ${ }^{-1}$ ) on 30 DAPwith the results of $\sqrt{\mathrm{x}+1}$ transformation.

\begin{tabular}{cccccc}
\hline \multirow{2}{*}{ Type of water } & \multicolumn{4}{c}{ Spraying Concentration } & \multirow{2}{*}{ HSD 5\% } \\
\cline { 2 - 5 } Cow urine & 20 & 40 & 60 & 80 & \\
\hline Catfish pond water & $6.93^{\mathrm{b}}{ }_{\mathrm{x}}$ & $8.39^{\mathrm{a}}{ }_{\mathrm{x}}$ & $7.35^{\mathrm{b}}{ }_{\mathrm{x}}$ & $7.57^{\mathrm{a}}{ }_{\mathrm{x}}$ & \multirow{2}{*}{0.32} \\
\hline
\end{tabular}

HSD 5\% 0.43

Information: The numbers followed by the letters in rows $(a, b)$ and columns $(x, y)$ of each plant age did not have differences from the 5\% HSD test.

The 5\% HSD test results (Table 10) showed that on observation of plant age 15 days after planting (DAP), combination of organic liquid cow urine with concentration of $40 \%$ (Equivalent to $40 \mathrm{~mL} \mathrm{L-1}$ ) resulted in average fresh weight of the highest stem of $2.72 \mathrm{~g}$ which was different from other concentrations, whereas the combination of liquid wastewater of catfish pond with concentration of $80 \%$ (Equivalent to $80 \mathrm{ml}$ L-1) gave the lowest fresh weight average of $1.85 \mathrm{~g}$ but that was not different at other concentration. On the contrary with the observation of the 30 DAP plant, combination of liquid wastewater of catfish pond with concentration of $80 \%$ (Equivalent with $80 \mathrm{ml}$ L-1) actually resulted the highest average fresh weight of stem that was $14.12 \mathrm{~g}$, which was different from other concentrations, whereas a concentration of $20 \%$ (Equivalent to $20 \mathrm{~mL}$ L-1), combination of liquid wastewater of catfish pond resulted the lowest average fresh weight of stem with average fresh weight of stem was $5.83 \mathrm{~g}$ which was different from other concentrations.

Fresh weight of plants (ton $\boldsymbol{h a}^{-1}$ ). The analysis of variance showed that the type of waste and spray concentration had no effect, but the interaction between treatments had an effect on the fresh weight of the plant (ton $\mathrm{ha}^{-1}$ ). The average weight is presented in Table 10.

The 5\% HSD test results (Table 11) showed that on observation of fresh weight of the plant (ton ha ${ }^{-1}$ ) the combination of organic cow urine liquid treatment with a concentration of $40 \%$ (equivalent to $40 \mathrm{~mL}$ $\mathrm{L}^{-1}$ ) yielded the highest fresh weight of the plant (ton ha ${ }^{-1}$ ) was 8.39 (ton ha ${ }^{-1}$ ), but that was not different at $80 \%$ concentration (Equivalent to $80 \mathrm{~mL} \mathrm{~L}^{-1}$ ), while combination of liquid wastewater of catfish pond of $20 \%$ (equivalent to $20 \mathrm{~mL} \mathrm{~L}^{-1}$ ) resulted in 
the lowest fresh weight of the plant that was $6.59\left(\right.$ ton $\mathrm{ha}^{-1}$ ) which was different at other concentrations.

\section{Discussions}

Interaction effect between type of organic wastewater and concentration of spraying. Based on the results of research on the utilization of organic wastewater with different concentrations on the growth and yield of bok choy plants showed that there was a very real interaction between organic wastewater type and spraying concentration on observation of leaf area, dry weight (root and stem), fresh weight (leaf and stems), as well as the fresh weight of the plant (ton ha ${ }^{-}$ ${ }^{1}$ ), but did not interact on observation of plant height, leaf number, leaf dry weight and fresh root weight. Based on the analysis of advanced HSD test at the 5\% level, it was found that the interaction between organic liquid waste concentration of $40 \%$ (Equivalent to $40 \mathrm{~mL} \mathrm{~L}^{-1}$ ) resulted in the widest leaf area, dry weight (root and stem), fresh weight (leaf and stem), the fresh weight of the plant (ton ha ${ }^{-1}$ ) were bigger than the other concentrations. It is presumed that organic liquid waste of cow urine with a concentration of $40 \%$ (Equivalent to 40

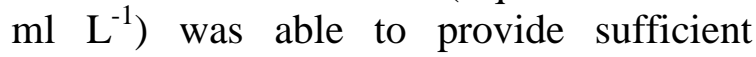
nutrients for growth and yield of bok choy plants. This is in accordance with the statement of Rizqiani et al (2007), which stated that the provision of liquid organic fertilizer can increase the number of leaves, number of branches, leaf area, leaf area index, root length, root volume, number of pods, fresh weight of pods per plant and fresh weight of pods per hectare in beans.

The effect oforganic wastewater type. Based on the results of research on the utilization of organic wastewater with different concentrations on the growth and yield of bok choy plants showed that the type of liquid organic waste had a very real effect on the observation of leaf area, leaf dry weight when the plant was 30 days after planting (DAP), root dry weight and fresh weight of stems on 15 DAP. Significant effect on the number of leaves at the age of 30 DAP plants and dry weight of stems when the plant was 15 DAP. Based on HSD test results at $5 \%$ level, indicated that organic cow urine produced a more average number of leaves, dry weight (stem, leaves and roots) that was heavier, wider leaf area, and heavier weight of stem more than liquid wastewater of catfish pond. This is due to the nitrogen content contained in the cow urine is higher than the organic liquid waste of catfish pond water according to the results of elemental content analysis presented in Table Annex 3b. This is in accordance with the statement of Mahrita (2003) that the higher dose of fertilizer given then the nitrogen needs by the plant is more fulfilled, where nitrogen is very important for plant growth that is for the formation and division of cells both in leaves, stems, and roots.

\section{Effect of Organic Wastewater Concentration} Spraying. Based on the results of research on the utilization of organic wastewater with different concentrations on the growth and yield of bok choy plants showed that the concentration of organic wastewater had a very significant effect on leaf area, leaf dry weight, root dry weight, dry weight of stem on 30 days after planting (DAP), fresh weight of leaves on 15 DAP, fresh root weight on 15 DAP, and fresh weight of stem. Significant effect on the dry weight of stem at the age of 15 DAP and fresh weight of leaves at the age of 30 DAP. Based on the analysis of advanced HSD test at 5\% level, it was found that at $40 \%$ concentration (Equivalent to $40 \mathrm{~mL} \mathrm{~L}^{-1}$ ) resulted in wider leaf area, dry weight (leaves, roots and stems when the plants were 30 days after planting) were heavier, and fresh weight (leaves, roots and stems when the plants were 15 DAP) were heavier than other concentrations. The result is assumed that at a concentration of $40 \%$ (equivalent to 40 $\mathrm{mL} \mathrm{L^{-1 }}$ ) of nutrients contained in organic wastewater in sufficient quantities to support the growth and yield of bok choy plants. While at lower concentrations the available nutrients are insufficient to 
support growth and improve the yield of bok choy. This is in accordance with the statement of (Sutedjo and Kartasapoetra, 1988) which stated that if the needs of nitrogen element is fulfilled, it can increase plant growth. As it is known the nitrogen element in the plant serves to increase the growth of the leaves so that the leaves will be many in number and will be wide with a greener color that will increase protein levels in the plant body (Sutedjo and Kartasapoetra, 1988).

In contrast to the research that has been done by Silalahi (2013), it was found that in giving cow urine up to the concentration of $60 \%$ to increase the height of mustard plant was real, but the concentration of $80 \%$ cow urine showed no significant effect with $60 \%$ concentration.

\section{CONCLUSION AND SUGGESTION}

\section{Conclusion}

Based on research on the utilization of organic wastewater with different concentration on the growth and yield of bok choy plants that have been implemented in Bolupontu Jaya hamlet, Sidera village, SigiBiromarusubdistrict, the following conclusion is obtained:

1. The interaction between the organic liquid of cow urine with concentration of $40 \%$ (equivalent to $40 \mathrm{~mL} \mathrm{~L}^{-1}$ ) yielded the widest leaf area, leaf dry weight, fresh weight (leaves, roots, and stems), fresh weight of plant (ton ha ${ }^{-1}$ ) was heavier of 8.39 (ton ha ${ }^{-1}$ ) than other interactions.

2. Liquid organic waste of cow urine gave better growth and yield of bok choy plants compared to organic liquid waste of catfish pond water.

3. The best concentration of organic wastewater was found at concentrations of $40 \%$ (equivalent to $40 \mathrm{~mL} \mathrm{~L}^{-1}$ ).

\section{Suggestion}

Based on the results of research that has been implemented, it is advisable to do analysis of Catfish pond water source more complete to support the research to be implemented.

\section{REFERENCES}

Deptan Propinsi DIY. 1999. Rekomendasi Pertanian Daerah. Yogyakart.

Devani, M, D. 2012. Pengaruh Bahan dan Dosis Kompos Cair Terhadap Pertumbuhan Selada (Lactuza sativa). Jurnal Agroteknologi Universitas Jambi : Jambi. 1 (1). 16 - 22.

Mahrita, 2003. Pengaruh Pemupukan $N$ dan Waktu Pemangkasan Pucuk Terhadap Pertumbuhan Dan Hasil Kacang Nagara. Agriscientiae 10 (2): 70-76.

Rizqiani, N. F., E. Ambarwati, dan N. W. Yuwono. 2007. Pengaruh Dosis dan Frekuensi Pemberian Pupuk Organik Cair terhadap Pertumbuhan dan Hasil Buncis (Phaseolus Vulgaris L.) Dataran rendah. Jurnal Ilmu Tanah danLingkungan, 7 (1) : 43-53.

Sutedjo, M.M dan A. G. Kartasapoetra. 1988. Pupukdan Cara Pemupukan. PT Bina Aksara. Jakarta. 